\title{
UTILIZATIION OF ORGANIC ACID FOR INHIBITING AFLATOXIN PRODUCED BY Aspergillus flavus IN STORED YELLOW CORN . \\ Abdel-Moneim, Ebtesam ${ }^{1}$; M.F. Emara; ${ }^{2}$ Reham, M. El-Tookhy ${ }^{2}$ \\ ${ }^{1}$ Biochemistry Department, Faculty of Agriculture, Cairo University. \\ ${ }^{2}$ Central Lab. for Food and Feed, Agricultural Research Center.
}

\begin{abstract}
The effect of organic acid mixtures on the growth of Aspergillus flavus and subsequently on the production of aflatoxins $B_{1}, B_{2}, G_{1}, G_{2}$ and total aflatoxins in yellow corn at two moisture levels, was investigated. Yellow corn grains was calibrated to moisture levels 15 and $20 \%$ and treated with combined application of propionic acid + acetic acid + formic acid at ratios 1:1:2 (mixture1), 1:2:2 (mixture2) and 1:2:3 (mixture3). A preliminary stepwise protocol starting from $0.2 \%$ to $1.0 \%$ concentration was used to determine the concentration of organic acid mixtures that can inhibit growth of $A$. flavus in yellow corn during 21 days. Then, the chosen concentrations were used in the main experiment which lasted 60 days. In yellow corn with $15 \%$ moisture, one concentration $(0.2 \%)$ was used to the main trial. When moisture was raised to $20 \%$, two concentrations were used $(0.8$ and $1.0 \%)$ to the main experiment. The trial included two groups of treatments, with and without $A$. flavus infection then, stored at room temperature $30^{\circ} \mathrm{C}$ and $25^{\circ} \mathrm{C}$ for 60 days. Results showed that $A$. flavus production increased with increasing moisture level, but decreased as the concentration of organic acid increased. Total fungal count increased during the whole period of the experiment in the control groups. At all storage conditions, mixture 3 showed less fungal inhibity effect. raising moisture content of yellow corn was up to $20 \%$, mixture 2 was found to be the best mold inhibitor at a concentration of $0.8 \%$. Incubation at $25^{\circ} \mathrm{C}$ was more effective than that at room temperature to reduce total aflatoxins. It could be concluded that, using $1.0 \%$ of mixture 1 and mixture 2 as preservatives inhibited both growth of $A$. flavus, and aflatoxin production in yellow corn stored whether at $25^{\circ} \mathrm{C}$ or ats room temperature during the 21 days of storage.
\end{abstract}

Keywords: Yellow corn, Aflatoxin, Aspergillus flavus, Propionic, Acetic, Formic.

\section{INTRODUCTION}

Large amounts of food and feed are lost annvally due to spoilage by moulds and yeasts (Helena Lind et al., 2004). Corn grains are often harvested at a moisture content which may enhance the growth, colonization and mycotoxins production by a range of fungi primary Aspergillus and Ppenicillum spp. Because Aspergillus and Penicillum spp. grow actively when grain moisture is greater than $16 \%$ drying of grain to less than $15 \%$ moisture after harvest is commonly used to control fungal growth (White and Toman, 1995). Delaying drying of grains was found to cause harmful effects for such grainss (Marine et al., 2002). Aflatoxins are a group of toxic, mutagenic and carcinogenic compounds (IARC, 1993). They are produced by toxigenic strains of Aspergillus flavus and A. paraciticus as secondary metabolites. Various foods may support the growth of these microorganisms and consequently lead to contamination with aflatoxins (Wood, 1989 and Ellis, 1991).The contamination may take place during growth, harvest, transportation and storage and thus is difficult to be prevented (Abdelhamid, 
2000). There are at least 16 naturally occurring aflatoxins, and the four major toxins are $B_{1}, B_{2}, G_{1}$ and $G_{2}$ (Rusul et al., 1987 and Abdelhamid, 1998). Aflatoxin $B_{1}$ is a potent hepatocarcinogen and mutagen (Heathcote, 1984 and Abdelhamid et al., 2002). One alternative to prevent or reduce aflatoxin production in stored grains for animal consumption, is the use of chemical fungal inhibitors, such as the salts of propionic acid (Abdelhamid et al., 1985 and Moreno et al., 2000).Volatile organic aicds such as acetic and propionic are commonly used in the food industry as preservatives (Rusul et al., 1987). Propionic acid followed by acetic acid were the most potent antifungals (Helena Lind et al., 2004). Acetic acid is more effective in limiting yeast and bacterial growth than mold growth (Doores, 1983). Propionic acid and the propionates are highly effective mold inhibitors but have little or no effect against yeasts, which is why these chemicals are used in the baking industry (Sauer, 1977). Formic acid is the most suitable chemical preservative for feeds because of its high bactericidal and fungicidal properties (Tagaev et al., 1985). It can be used alone or in combination with other acids and it has no adverse effect on farm animals. Combined application of propionic acid + acetic acid at $1: 1$ ratio $(1.0,2.5,5.0 \%)$ completely inhibited aflatoxin $B_{1}$ production (Kavita Waghray and Reddy, 2000). The objectives of this study were to investigate the effectiveness of different mixtures of propionic, acetic and formic acids as preservatives and to determine their effect on growth and aflatoxin production by molds under different storage conditions.

\section{MATERIALS AND METHODS}

\section{Design of the experiment:}

A stepwise preliminary experiment was carried outto determine the concentration of organic acids, mixtures that can inhibit growth of Aspergillus flavus in treated yellow corn during 21 days. Then, the chosen concentrations were used in the main experiment which lasted 60 days. Different concentrations of the examined organic acids, mixtures were prepared using autoclaved distilled water as a diluent. Five concentrations were used for this experiment $(0.2,0.4,0.6,0.8$ and $1.0 \%)$ at two moisture contents of yellow corn $(15 \%$ and $20 \%)$. Three organic acids, mixtures were used in the experiment according to the ratio of propionic : acetic : formic. These ratios were 1: 1:2, 1:2: 2 and 1:2: 3 for mixture 1, 2 and 3, respectively. An amount of $14.4 \mathrm{Kg}$ of yellow corn $14 \%$ moisture was used for the whole experiment as follow:

Moisture content of $2.4 \mathrm{~kg}$ yellow corn was adjusted to be $15 \%$, and then equally divided into 24 sterile Erlenmeyer flasks; each flask contained $100 \mathrm{gm}$ of yellow corn sample. These flasks were divided into 2 groups.

In group 1, yellow corn (16 flasks) was infected by Aspergillus flavus and divided into 2 subgroups according to incubation temperature. The first subgroup (8 samples) was incubated in incubator at $25^{\circ} \mathrm{C}$, while the second subgroup (8 samples) was incubated at room temperature at $30^{\circ} \mathrm{C}$. Each two samples were treated the same treatment with the first tested concentration $(0.2 \%$ of organic acids, mixtures). According to the obtained results, this 
concentration was chosen to complete the main experiment. One flask was left without inoculation as acontrol. One sample was used to determine the growth of Aspergillus flavus, while the other sample was used to evaluate the aflatoxins content.

Yellow corn in group 2 (8 flasks) was divided and treated with the $0.2 \%$ organic acids, mixtures without any infection. This group was divided also to 2 subgroups according to the incubation temperature (room temperature and $25^{\circ} \mathrm{C}$ ). Only one sample for each treatment was used to determine the growth of Aspergillus flavus.

When yellow corn moisture was adjusted to be $20 \%$, amount of 12.0 $\mathrm{kg}$ yellow corn was used in the experiment. Every $2.4 \mathrm{~kg}$ of yellow corn was divided as mentioned spreviously and treated with the tested concentration. Five mixture concentrations $(0.2,0.4,0.6,0.8$ and $1.0 \%)$ were used as a stepwise protocol for these samples, and concentrations of 0.8 and $1.0 \%$ were shosen to complete the main experiment.

The count of $A$. flavus was determined at days $0,7,14,21,28$ and 60 for all samples used for the main experiment, while, aflatoxin values were determined only in the infected samples after 21 days of inoculation.

Aflatoxin production:

Aspergillus flavus NRRRL (3145) was obtained from the Natural Research Center (Dokki, Cairo). Inoculum was prepared by inoculating tubes $(1.5 \times 1.5 \mathrm{~cm})$ containing Rozebengal with spores of Aspergillus flavus NRRL (3145). Incubated slants were incubated for 5 days at $25^{\circ} \mathrm{C}$ (Shotwell et al., 1966).

Infection of yellow corn:

Yellow corn was obtained from Cairo Poultry Company, Giza, Egypt and deliberately infected with Aspergillus flavus NRRL (3145) which was grown on Rozebengal slant and characterized by crop of green conidia. The spores were scraped by adding sterile distilled water to the surface growth on the slants and an aliquot from the resulting spore suspension $(1 \mathrm{ml})$ was added to conical flasks (2 liter) containing yellow corn (previously autoclaved to prevent surface contamination).

\section{Extraction of aflatoxins:}

Standard of aflatoxins: $B_{1}, B_{2}, G_{1}$ and $G_{2}$ were obtained from Sigma Chemical Company (St. Louis, MO USA). The extraction of aflatoxins was conducted according to A.O.A.C. method (1990). The samples were blended with $250 \mathrm{ml}$ methanol-water $(55: 45, \mathrm{v} / \mathrm{v})$ and $100 \mathrm{ml}$ hexane for $1 \mathrm{~min}$. at high speed. The mixture was transferred to $u$ centrifuge bottle and centrifuged for $5 \mathrm{~min}$. at $2000 \mathrm{rpm}$ and an aliquot from the aqueous methanol phase $(25 \mathrm{ml})$ was taken with chloroform into a separatory funnel shaken for (30-60 sec.), the bottom layer (chloroform) was separated and concentrated using rotary vacuum evaporator. The residue was quantitatively transferred using small volumes of chloroform. The solvent was completely removed under nitrogen and stored at $0{ }^{\circ} \mathrm{C}$ until quantitative analysis.

Determination of aflatoxins:

Aflatoxins were determined using thin layer chromatographic technique as describedby (Shanon et al., 1983 and A.O.A.C., 1990). 


\section{Determination and adjustment of the moisture content of corn before inoculation:}

Moisture contents of corn samples was estimated according to (AOAC, 1998 ) then adjusted to be $15 \%$ and $20 \%$ according to the following equation: Where $S=$ the volume of water required for $100 \mathrm{~g}$ of samples to reach the required level of moisture content.

\section{The total fungal count was performed as follows:}

Five grams of each sample were added to a $45 \mathrm{ml}$ sterile saline solution in $500 \mathrm{ml}$ Erlenmeyer flasks and homogenized thoroughly on an electric shaker at a constant speed. Tenfold serial dilutions were then prepared. One $\mathrm{ml}$ portion of three suitable dilutions of the resulting sample suspension was used to inoculate Petri dishes each containing $15 \mathrm{ml}$ Rosebengal containing $0.5 \mathrm{mg}$ Chloramphenicol $/ \mathrm{ml}$ medium to inhibit bacterial growth Plate were then incubated for 5 days at $25^{\circ} \mathrm{C}$ and the fungal colonies were counted (Aziz, 1998).

\section{Criteria of acceptance:}

The criteria of evaluation of antifungal activity were estimated according to European Pharmacopoeia (2001) in terms of the log reduction in the number of viable microorganisms against the value obtained for the fungal count at zero time.

\section{RESULTS AND DISCUSSION}

At initial yellow corn moisture of $15 \%$, minimum concentration inhibited growth of $A$. flavus was $0.2 \%$ for all treatments. When the initial moisture was raised to $20 \%$, there was a negative effect for all used preservative mixtures when concentrations of $0.2,0.4$ and $0.6 \%$. The effective values were 0.8 and $1.0 \%$ for all mixtures. Based on these results, concentrations of organic acids, mixtures chosen for further experiments with the yellow corn at moisture of $15 \%$ was $0.2 \%$. When the initial moisture was $20 \%$, the chosen concentrations were 0.8 and $1.0 \%$.

\section{Fungal activity and count:}

It is clear from the obtained data (Tables 1-3) that, stotal fungal count increased during the whole period of the experiment in the control groups which, were not treated with any preservative. This result is supported by Philip et al., 1983, Marine et al., 2002 and El-Moghazy et al., 2003, who stated that in the absence of preservatives fungal growth is fast and obvious.

Table (1) shows the fungal growth in yellow corn containing $15 \%$ moisture and treated with $0.2 \%$ acid mixtures. The three grains mixtures have been affected after one week hence reduction of the log number by 1 in the infected and non infected samples was recorded. 
Table (1): The count of Asperagillus flavus colonies (cfu/g) produced from an infected and non infected yellow corn containing $15 \%$ moisture treated with $0.2 \%$ various mixtures of propionic, acetic and formic acids and stored at room temperature and $25^{\circ} \mathrm{C}$.

\begin{tabular}{|c|c|c|c|c|c|c|c|c|}
\hline \multirow{2}{*}{$\begin{array}{c}\text { Duration of } \\
\text { incubation } \\
\text { (Day) }\end{array}$} & \multicolumn{2}{|c|}{ Control } & \multicolumn{2}{|c|}{ Mixture 1} & \multicolumn{2}{|c|}{ Mixture 2} & \multicolumn{2}{|c|}{ Mixture 3} \\
\hline & Infected & $\begin{array}{c}\text { Non } \\
\text { infected }\end{array}$ & Infected & $\begin{array}{c}\text { Non } \\
\text { infected }\end{array}$ & Infected & $\begin{array}{c}\text { Non } \\
\text { infected }\end{array}$ & Infected & $\begin{array}{c}\text { Non } \\
\text { infected }\end{array}$ \\
\hline \multicolumn{9}{|c|}{ At room temperature } \\
\hline 0 & $>50 \times 10^{2}$ & $>50 \times 10^{2}$ & $65 \times 10^{2}$ & $>50 \times 10$ & $>50 \times 10^{2}$ & $>50 \times 10^{2}$ & $>50 \times 10$ & $>50 \times 10^{2}$ \\
\hline 7 & $18 \times 10$ & $22 \times 10$ & $1 \times 10$ & $4 \times 10$ & $4 \times 10$ & $4 \times 10$ & $5 \times 10$ & $5 \times 10$ \\
\hline 14 & $16 \times 10$ & $23 \times 10$ & $1 \times 10$ & $1 \times 10$ & $2 \times 10$ & -ve & $3 \times 10$ & $3 \times 10$ \\
\hline 21 & $8 \times 10$ & $8 \times 10$ & -ve & -ve & $1 \times 10$ & -ve & $1 \times 10$ & $1 \times 10$ \\
\hline 28 & $12 \times 10$ & $6 \times 10$ & -ve & -ve & -ve & -ve & -ve & $1 \times 10$ \\
\hline 60 & $12 \times 10$ & $6 \times 10$ & -ve & -ve & -ve & -ve & -ve & $1 \times 10$ \\
\hline \multicolumn{9}{|l|}{ At $25^{\circ} \mathrm{C}$} \\
\hline 0 & $>50 \times 10$ & $50 \times 10$ & $>50 \times 10^{2}$ & $>50 \times 10^{2}$ & $<50 \times 10$ & $>50 \times 10^{2}$ & $<50 \times 10$ & $<50 \times 10$ \\
\hline 7 & $13 \times 10$ & $12 \times 10$ & $1 \times 10$ & $2 \times 10$ & $4 \times 10$ & $4 \times 10$ & $5 \times 10$ & $6 \times 10$ \\
\hline 14 & $18 \times 10$ & $17 \times 10$ & -ve & $1 \times 10$ & $10 \times 10$ & $2 \times 10$ & $3 \times 10$ & $6 \times 10$ \\
\hline 21 & $11 \times 10$ & $4 \times 10$ & -ve & -ve & $6 \times 10$ & $1 \times 10$ & $3 \times 10$ & $6 \times 10$ \\
\hline 28 & $37 \times 10$ & $18 \times 10$ & -ve & -ve & $2 \times 10$ & -ve & -ve & $2 \times 10$ \\
\hline 60 & $16 \times 10$ & $11 \times 10$ & -ve & -ve & $2 \times 10$ & -ve & -ve & $1 \times 10$ \\
\hline
\end{tabular}

-ve=negative

After three weeks of storage, no A. flavus growth was found in yellow corn treated with mixtures 1 and 2, except those non infected and treated with mixture 2. When yellow corn was incubated at $25^{\circ} \mathrm{C}$, the effect of mixture 2 was declined. No complete inhibition was found in grains treated with mixture 2 during 60 days. Mixture1(25\% propionic acid) was found to be the best preservative, hence log number was reduced by 1 after one week of the inoculation and complete inhibition was occurred after three weeks. This result may indicate that propionic acid has a superior antifungal effect. Gowda et al., 2004 stated that propionic acid at 0.1-0.5\%completely inhibited Aspergillus parasiticus growth. Higgins and Brinkhaus, 1999 demonstrated that propionic acid showed the highest effect against moulds with the effective concentrations ranging from 0.05 to $0.25 \%$; whereas acetic acid required concentrations of $10 \mathrm{lb} /$ ton or more for effective mould inhibition.

At all storage conditions, mixture 3 has a weak inhibition effect on $A$. flavus. This may due to the lowest percentage of propionic acid (16.66\%) and the highest percentage of formic acid (49.99\%) in mixture 3 . This is in agreement with Holmberg et al., 1989a who isolated $A$. flavus or $A$. parasiticus originating from acid-treated feed grain. Formic acid was less effective than propionic acid in inhibiting fungal growth. No growth was found on plates with $0.3 \%$ propionic acid, but on plates with $0.3 \%$ formic acid growth was observed in $21 \%$ of the isolates, all originating from formic acidtreated grain. Holmberg et al., 1989b stated that, growth of $A$. parasiticus and aflatoxin production was restricted in propionic acid-treated grain. In grain treated with formic acid alone, $A$. parasiticus totally dominated the fungal flora and produced high levels of aflatoxins. 
At $20 \%$ moisture content in yellow corn, mixture 2 followed by mixture 1 were found to be the best mold inhibitors at a concentration of $0.8 \%$ (Table 2).

Mixture 2 inhibited completely the growth of $A$. flavus after 7 days in the stored yellow corn except those infected and stored at room temperature which the complete inhibition was found after 14 days. Reduction in mold count by using mixtures 1 and 2 was greater than the reduction caused by mixture 3 .

Table (2): The count of Asperagillus flavus colonies (cfu/g) produced from an infected and non infected yellow corn containing $20 \%$ moisture treated with $0.8 \%$ various mixtures of propionic, acetic and formic acids and stored at room temperature and $25^{\circ} \mathrm{C}$.

\begin{tabular}{|c|c|c|c|c|c|c|c|c|}
\hline \multirow{2}{*}{$\begin{array}{c}\text { Duration of } \\
\text { incubation } \\
\text { (Day) }\end{array}$} & \multicolumn{2}{|c|}{ Control } & \multicolumn{2}{|c|}{ Mixture 1} & \multicolumn{2}{|c|}{ Mixture 2} & \multicolumn{2}{|c|}{ Mixture 3} \\
\hline & Infected & $\begin{array}{c}\text { Non } \\
\text { infected }\end{array}$ & Infected & $\begin{array}{c}\text { Non } \\
\text { infected }\end{array}$ & Infected & $\begin{array}{c}\text { Non } \\
\text { infected }\end{array}$ & Infected & $\begin{array}{c}\text { Non } \\
\text { infected }\end{array}$ \\
\hline \multicolumn{9}{|c|}{ At room temperature } \\
\hline 0 & $12 \times 10^{3}$ & $68 \times 10$ & $10^{2}$ & $32 \times 10$ & $10^{3}$ & $21 \times 10$ & $94 \times 10^{2}$ & $49 \times 10$ \\
\hline 7 & $>10^{3}$ & $10^{3}$ & $18 \times 10$ & $1 \times 10$ & $60 \times 10$ & -ve & $10^{2}$ & -ve \\
\hline 14 & $10^{3}$ & $10^{3}$ & $10 \times 10$ & $3 \times 10$ & $-\mathrm{ve}$ & -ve & $3 \times 10$ & -ve \\
\hline 21 & $>10^{3}$ & $>10^{3}$ & -ve & -ve & -ve & -ve & $6 \times 10$ & -ve \\
\hline 28 & $>10^{3}$ & $>10^{3}$ & -ve & -ve & -ve & -ve & $6 \times 10$ & -ve \\
\hline 60 & $10^{4}$ & $>10^{3}$ & -ve & -ve & -ve & -ve & -ve & -ve \\
\hline \multicolumn{9}{|l|}{ At $25^{\circ} \mathrm{C}$} \\
\hline 0 & $10^{3}$ & $68 \times 10$ & $20 \times 10^{2}$ & $26 \times 10$ & $100 \times 102$ & $50 \times 10$ & $91 \times 102$ & $66 \times 10$ \\
\hline 7 & $10^{3}$ & $10^{3}$ & $1 \times 10$ & $1 \times 10$ & -ve & -ve & $17 \times 10$ & $1 \times 10$ \\
\hline 14 & $10^{3}$ & $10^{3}$ & -ve & -ve & -ve & -ve & $1 \times 10$ & -ve \\
\hline 21 & $10^{3}$ & $>10^{3}$ & -ve & -ve & -ve & -ve & $4 \times 10$ & -ve \\
\hline 28 & $10^{3}$ & $>10^{3}$ & -ve & -ve & -ve & -ve & $4 \times 10$ & -ve \\
\hline 60 & $10^{4}$ & $>10^{3}$ & -ve & -ve & -ve & -ve & -ve & -ve \\
\hline
\end{tabular}

The effect of raising the chemical preservatives concentration to $1.0 \%$ is presented in table (3). The A. flavus colonies were prevented completely after 7 days in all samples treated with mixture 1 . Using mixture 2, reduced the log number by 1 after 7 days and completely removed all colonies after 14 days. Mixture 3 showed the same weak effect even after raising its concentration from 0.8 to $1.0 \%$ (tables 2 and 3 ). 
Table (3): The count of Asperagillus flavus colonies (cfu/g) produced from an infected and non infected yellow corn containing $20 \%$ moisture treated with $1.0 \%$ various mixtures of propionic, acetic and formic acids and stored at room temperature and $25^{\circ} \mathrm{C}$.

\begin{tabular}{|c|c|c|c|c|c|c|c|c|}
\hline \multirow{2}{*}{$\begin{array}{c}\text { Duration of } \\
\text { incubation } \\
\text { (Day) }\end{array}$} & \multicolumn{2}{|c|}{ Control } & \multicolumn{2}{|c|}{ Mixture 1} & \multicolumn{2}{|c|}{ Mixture 2} & \multicolumn{2}{|c|}{ Mixture 3} \\
\hline & Infected & $\begin{array}{c}\text { Non } \\
\text { infected }\end{array}$ & Infected & $\begin{array}{c}\text { Non } \\
\text { infected }\end{array}$ & Infected & $\begin{array}{c}\text { Non } \\
\text { infected }\end{array}$ & Infected & $\begin{array}{c}\text { Non } \\
\text { infected }\end{array}$ \\
\hline \multicolumn{9}{|c|}{ At room temperature } \\
\hline 0 & $96 \times 10^{2}$ & $73 \times 10$ & $98 \times 10^{2}$ & $10^{2}$ & $10^{2}$ & $46 \times 10$ & $10^{2}$ & $21 \times 10^{2}$ \\
\hline 7 & $10^{3}$ & $10^{3}$ & -ve & -ve & $73 \times 10$ & $1 \times 10$ & $3 \times 10$ & $5 \times 10$ \\
\hline 14 & $>10^{3}$ & $10^{3}$ & -ve & -ve & -ve & -ve & $1 \times 10$ & -ve \\
\hline 21 & $>10^{3}$ & $>10^{3}$ & -ve & -ve & -ve & -ve & $2 \times 10$ & -ve \\
\hline 28 & $>10^{3}$ & $>10^{3}$ & -ve & -ve & -ve & -ve & -ve & -ve \\
\hline 60 & $>10^{3}$ & $>10^{3}$ & -ve & -ve & -ve & -ve & -ve & -ve \\
\hline \multicolumn{9}{|l|}{ At $25^{\circ} \mathrm{C}$} \\
\hline 0 & $101 \times 10^{2}$ & $46 \times 10^{2}$ & $10^{2}$ & $49 \times 10$ & $10^{2}$ & $20 \times 10$ & $10^{2}$ & $72 \times 10$ \\
\hline 7 & $10^{3}$ & $10^{3}$ & -ve & -ve & $6 \times 10$ & -ve & $66 \times 10$ & $1 \times 10$ \\
\hline 14 & $>10^{3}$ & $10^{3}$ & -ve & -ve & - ve & -ve & $19 \times 10$ & -ve \\
\hline 21 & $>10^{3}$ & $>10^{3}$ & -ve & -ve & -ve & -ve & -ve & -ve \\
\hline 28 & $>10^{3}$ & $>10^{3}$ & -ve & -ve & -ve & -ve & -ve & -ve \\
\hline 60 & $>10^{3}$ & $>10^{3}$ & -ve & -ve & -ve & -ve & -ve & -ve \\
\hline
\end{tabular}

\section{Biosynthesis and accumulation of aflatoxins:}

Data in tables 4 and 5 indicated that biosynthesis and accumulation of aflatoxins were mostly influenced by the concentration of mixture, incubation temperature and type of mixture. Generally, after 21 days of incubation, an increase of preservative concentration from $0.8 \%$ to $1.0 \%$ was associated with a decrease of amount of aflatoxins $B_{1}, B_{2}, G_{1}, G_{2}$ and total aflatoxins.

There were no differences observed in amount of aflatoxin $B_{1}, B_{2}, G_{1}$ and $\mathrm{G}_{2}$ produced by cultures growing either at room temperature in an incubator at $25^{\circ} \mathrm{C}$. In general, incubation at $25^{\circ} \mathrm{C}$ was the more be effective than room temperature to reduce total aflatoxin in stored yellow corn. This may due to the room temperature which was more than $25^{\circ} \mathrm{C}$ during summer period.

It is clear that, aflatoxins $B_{1}, B_{2}, G_{1}, G_{2}$ and total aflatoxins in the control were higher than those of other treatments. Aflatoxins of yellow corn treated with $0.8 \%$ organic acid mixtures are shown in Table (4).

Mixture 2 was the best preservative to inhibit the accumulation of all types of aflatoxins and total aflatoxins. No accumulation of aflatoxin $B_{1}, B_{2}$ and $G_{1}$ was found in yellow corn treated with mixtures 1 and 2 under $25^{\circ} \mathrm{C}$ incubation. The lowest total aflatoxin values were found in the yellow corn treated with mixture $2\left(3.94\right.$ and $24.71 \mathrm{ppb}$ at $25^{\circ} \mathrm{C}$ and room temperature, respectively). Raising the mixture concentration to $1.0 \%$ (Table 5), showed no accumulation of aflatoxin $B_{1}$ and $B_{2}$ was in yellow corn treated with any of the three mixtures either incubated at room temperature or $25^{\circ} \mathrm{C}$. This is in agreement with Verma et al., 2000 who indicated that aflatoxin $\mathrm{B}_{1}$ biosynthesis increased with increasing moisture levels, and decreased as the concentration of organic acids increased. 
Table (4): Accumulation of aflatoxin (AN) B1, B2, G1, G2, and total aflatoxins (ppb) in an infected yellow corn containing $20 \%$ moisture treated with $0.8 \%$ various mixtures of propionic, acetic and formic acids under different incubation conditions after 21 days of incubation.

\begin{tabular}{|c|c|c|c|c|c|}
\hline \multicolumn{2}{|c|}{$\begin{array}{l}\text { Type } \\
\text { of AN }\end{array}$} & Control & Mix 1 & Mix 2 & Mix 3 \\
\hline \multirow{2}{*}{ B1 } & Room Temperature & 491.01 & 31.49 & - & - \\
\cline { 2 - 6 } & $25^{\circ} \mathrm{C}$ & 662.75 & - & - & 31.58 \\
\hline \multirow{2}{*}{ B2 } & Room Temperature & 15.41 & 16.7 & - & - \\
\cline { 2 - 6 } & $25^{\circ} \mathrm{C}$ & 111.17 & - & - & 9.97 \\
\hline \multirow{2}{*}{$\mathrm{G} 1$} & Room Temperature & 833.90 & 32.69 & 17.44 & 25.11 \\
\cline { 2 - 6 } & $25{ }^{\circ} \mathrm{C}$ & 1559.24 & - & - & 57.90 \\
\hline \multirow{2}{*}{$\mathrm{G} 2$} & Room Temperature & 258.06 & 17.57 & $7 . .27$ & 7.95 \\
\cline { 2 - 6 } & $25^{\circ} \mathrm{C}$ & 325 & 9.01 & $3 . .94$ & 14.42 \\
\hline \multirow{2}{*}{$\begin{array}{l}\text { Total } \\
\text { aflatoxins }\end{array}$} & Room Temperature & 1738.38 & 98.45 & 24.71 & 33.06 \\
\cline { 2 - 6 } & 2658.16 & 9.01 & 3.94 & 13.87 \\
\hline
\end{tabular}

Table (5): Accumulation of aflatoxin (AN) B1, B2, G1, G2, and total aflatoxin (ppb) in an infected yellow corn containing $20 \%$ moisture treated with $1.0 \%$ various mixtures of propionic, acetic and formic acids under different incubation conditions after 21 days of inoculation.

\begin{tabular}{|c|l|c|c|c|c|}
\hline \multirow{2}{*}{$\begin{array}{c}\text { Type } \\
\text { of AN }\end{array}$} & \multicolumn{1}{|c|}{ Treat } & Control & Mix 1 & Mix 2 & Mix 3 \\
\hline \multirow{2}{*}{ B1 } & Room Temperature & 780.28 & - & - & - \\
\cline { 2 - 6 } & $25^{\circ} \mathrm{C}$ & 694.19 & - & - & - \\
\hline \multirow{2}{*}{ B2 } & Room Temperature & 294.34 & - & - & - \\
\cline { 2 - 6 } & $25^{\circ} \mathrm{C}$ & 142.19 & - & - & - \\
\hline \multirow{2}{*}{ G1 } & Room Temperature & 1542.18 & 25.81 & 57.90 & 47.44 \\
\cline { 2 - 6 } & $25^{\circ} \mathrm{C}$ & 2218.50 & - & - & 31.39 \\
\hline \multirow{2}{*}{ G2 } & Room Temperature & 681.81 & 10.54 & 6.53 & 8.62 \\
\cline { 2 - 6 } & $25^{\circ} \mathrm{C}$ & 530.90 & 11.07 & 11.65 & 6.74 \\
\hline \multirow{2}{*}{$\begin{array}{c}\text { Total } \\
\text { aflatoxins }\end{array}$} & Room Temperature & 3298.6 & 36.65 & 64.43 & 56.06 \\
\cline { 2 - 6 } & $25^{\circ} \mathrm{C}$ & 3585.78 & 11.07 & 11.65 & 38.13 \\
\hline
\end{tabular}

Generally, the results showed that mixtures 1 and 2 were the most effective preservatives against total aflatoxins and aflatoxin $B_{1}$. This result may due to the high percentages of propionic acid in mixture 1 (1 propionic : 1 acetic : 2 formic) and mixture 2 (1 propionic : 2 acetic : 2 formic).

Propionic acid at $0.05-0.5 \%$ completely inhibited aflatoxin production (Gowda et al., 2004). Concentrations over 60 ppm undissociated propionic acid concentration did not show an increase in aflatoxin $G_{1}$ and aflatoxin $B_{1}$ indicating that there is no need to increase the concentration of propionic acid over this value (Molina and Giannuzzi, 2002). At 10\% moisture levels, $0.5 \%$ propionic acid and $1 \%$ acetic acid were effective in preventing the growth of $A$. flavus and subsequent aflatoxin $\mathrm{B}_{1}$ production. Propionic acid was the 
most effective in the prevention of aflatoxin $B_{1}$, followed by acetic acids (Verma et al., 2000). Kavita Waghray and Reddy, 2000 stated that individual or combined application of propionic acid and acetic acid at 1.0, 2.5 and 5.0\% completely inhibited aflatoxin $\mathrm{B}_{1}$ production by Aspergillus flavus on maize.

It could be concluded that, during 21 days of storage, using $1.0 \%$ of mixture 1 (1 propionic : 2 acetic : 2 formic) and mixture 2 (1 propionic : 2 acetic : 2 formic) as preservatives inhibited both growth of $A$. flavus, and its aflatoxin production on yellow corn stored at $25^{\circ} \mathrm{C}$ or at room temperature.

\section{REFFERENCES}

A.O.A.C. (1990). Association of Official Analytical Chemists. Official Methods of Analysis. $15^{\text {th }}$ Ed. Kenneth helrich edit. Published by A.O.A.C. Inc., Virginia, U.S.A.

A.O.A.C. (1998). Association of Official Analytical Chemists. Official Methods of Analysis. $16^{\text {th }}$ Ed. Published by A.O.A.C. Benjamin Franklin station, Washington, D.C.

Abdelhamid, A.M. (1998). Short Speaking in Food Injuries. Deposit No. 7106/1998.

Abdelhamid, A.M. (2000). Fungi and Mycotoxins. Dar Al-Nashr for Universities. Deposit No. 13738/1997.

Abdelhamid, A.M., Sadik, E.A. and Fayzalla, E.A. (1985). Preserving power of some additives against fungal invasion and mycotoxin production in stored-crushed-corn containing different levels of moisture. Acta Phytopathologica Academca Scientiarum Hungariacae, 20: 309-320.

Abdelhamid, A.M., Sallam, A.E., Abd Allah, G.A. and El-Samra, S.H. (2002). Effect of feeding male rats on aflatoxic diets without or with medicinal herbs (thyme, safflower, ginger, black cumin, and/or garlic). Proc. $2^{\text {nd }}$ conf. on Food borne Contamination and Egyptian's Health, April 23-24, Mansoura Fac. Agric., pp:99-121.

Aziz, S.Y. (1998). Evaluation of physical methods to control mycotoxins in some contaminated foods. Agricultural Research Center, Food Technology Research. 76(2): 813-824.

Doores, S. (1983). Organic acids. In A. L. Branen and M. P. Davidson (eds.). Antimicrobials in Foods. Marcel Dekker, Inc., New York. 75-99.

Ellis, W.O, Smith, J.P. and Simpson, B.K. (1991). Aflatoxins in food: Occurrence, biosynthesis, effects on organism, detection and methods for control. Crit. rev. Food Sci. Nutr., 30:403-439.

El-Moghazy, G.M., Emara, M.F. Youssef, Mervat H. and Hamza, (2003). Antifungal activity of some organic acids used as feed preservatives. J. Agric. Mansoura Univ., 28(12): 8053-8061.

European Pharmacopia (2001). Council of Europe. $3^{\text {rd }}$ ed. ISBN 92871443188.

Gowda, N. K. S., Malathi, V., Suganthi, R. U. (2004). Effect of some chemical and herbal compounds on growth of Aspergillus parasiticus and aflatoxin production. Animal Feed Science and Technology, 116(3/4): 281-291. 
Heathcote, J.G. (1984). Aflatoxins and related toxins. In: V. Betina (ed.), Mycotoxins- Production, Isolation, Separation and Purification. Elsevier Science Publishers B. V., Amsterdam, Netherlands.p: 89-130.

Helena L., Hans J., Johan, S. (2004). Antifungal effect of dairy propionibacteria - contribution of organic acids. International Journal of Food Microbiology, Available online 24 August 2004.

Higgins, C. and Brinkhaus, F.(1999). Efficacy of several organic acids against molds. Journal of Applied Poultry Research, 8 (4): 480-487.

Holmberg, T., Kaspersson, A., Goransson, B., Kozakiewicz, Z. and Kramnas, L.( 1989a). Aflatoxin production and tolerance to organic acids by Aspergillus flavus and Aspergillus parasiticus isolated from acid treated moist grain. Acta Agriculturae Scandinavica, 39 (4): 449-455.

Holmberg, T., Kaspersson, A., Larsson, K. and Pettersson, H. (1989b). Aflatoxin production in moist barley treated with suboptimal doses of formic and propionic acid. Acta Agriculturae Scandinavica, 39(4): 457464.

IRAC, (1993). Some naturally occurring substance: Food items and constituents, Heterocyclic aromatic amines and mycotoxins, 56. Peltonen, D.K., El-Nazami, S.H., Salminen, L.S. and Ahokas, T.J. (2000). Binding of aflatoxin $B_{1}$ by probiotic bacteria. J. Society Food Agric., 80:1942-1954.

Kavita, Waghray and Reddy, M. U.(2000). Effect of chemicals on aflatoxin $B_{1}$ production, germination and viability in maize and groundnuts. Journal of Research ANGRAU. Acharya N G Ranga Agricultural University, Hyderabad, India: 28(1/2): 57-64.

Marine, S., Guyont, M.E., Neira, P., Bernado, M., Sanchis, V. and Ramos, A.J. (2002). Risk assessment of the use of sub-optimal levels of weak acids preservatives in the control of mould growth o bakery products. International Journal Food Microbiology, 79:203-211.

Molina, M., Giannuzzi, L.( 2002). Modelling of aflatoxin production by Aspergillus parasiticus in a solid medium at different temperatures, $\mathrm{pH}$ and propionic acid concentrations. Food Research International, 35(6): 585-594.

Moreno, M.E., Vazquez, B.M. and Facio, P.F. (2000). Use of propionic acid salts to inhibit aflatoxin production in stored grains of maize. Agrociencia, 34:477-484.

Philip, A.S., S.N. Talmadge, K. Linda Kirby, B.J. Zelpha and N.B. Joseph (1983). Influence of moisture, temperature and propionic acid on mold growth and toxin production on corn. Poultry Science, 62:419-423.

Rusul, G., El-Gazzar, E.F. and Marth, H.E. (1987). Growth and aflatoxin production by Aspergillus parasiticus NRRL 2999 in the presence of acetic or propionic acid and at different initial $\mathrm{pH}$ value. Journal of Food Protection, 50:909-914.

Sauer, F. (1977). Contorl of yeasts and molds with preservatives. Food Technology, 31:66-67.

Shanon, G.M., Shotwell, P.L. and Kwolek, W.F. (1983). Extraction and thinlayer chromatography of aflatoxin B1 in mixed feeds. J. Assoc. Anal. Chem., 66: 582-586. 
Shotwell, O.L., Hesseltine, C.W., Stubblefield, R.D. and Sorenson, W.G. (1966). Production of aflatoxin on rice. Appl. Microbial., 14: 425-428.

Tagaev, O.A., Pazderskii, Y.A., Popovich, B.D., Vrydnyk, F.I., White, D.G. and Toman, J.Jr. (1985). Postharvest application of low rates of DMX-7 mold inhibitor on storage fungi of corn during ambient air drying and storage. American Society of Agricultural Engineers, 11:573-576.

Verma, R. K., Bedi, P. S. and Agarwal, R. K.( 2000). Inhibitive effect of organic acids on aflatoxin production in groundnut cake. Indian Journal of Toxicology, 7(2): 117-119.

White, D. G. and Toman, J., Jr. (1995). Postharvest application of low rates of DMX-7 mold inhibitor on storage fungi of corn during ambient air drying and storage. Applied Engineering in Agriculture. 11(4): 573-576.

Wood, G.E. (1989). Aflatoxin in domestic and imported foods and feeds. J. Assoc. Off. Anl. Chem., 72:543-548.

استخام بعض مخاليط الأحماض العضوية لتثبيط انتاج الافلاتوكسينات الناتجة من التن فطريـات Aspergillus flavus في الأذرة الصفراء تحت ظروف التخزين

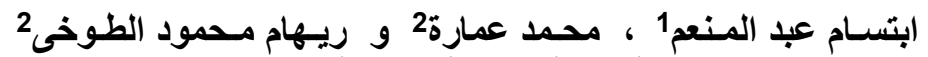

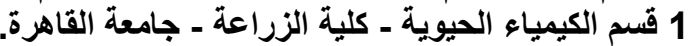
2 المعمل المركزى للأغذية و الأعلاف ـ مركز البحوثة الزية الزراعية.

فى هذه التجربة نم دراسة نأثير المخاليط الأحماض العضوية على نمو فطريات و إنتاج الأفلاتو كسينات Aspergillus flavus

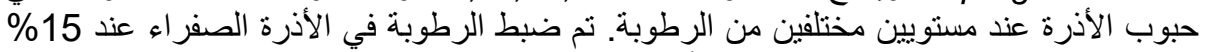

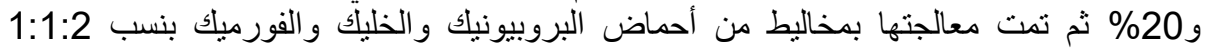

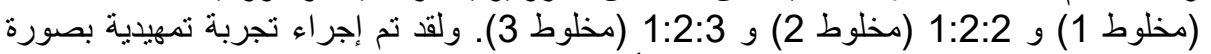

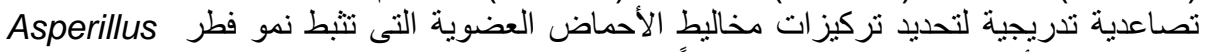

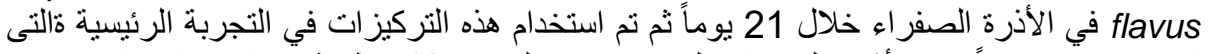

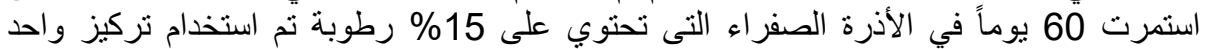

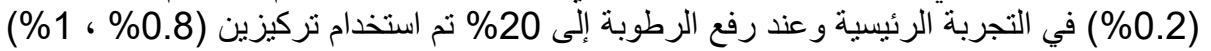

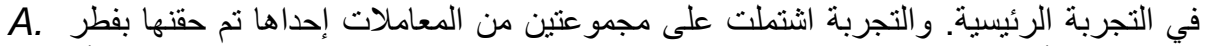
flavus درجة حرارة 25 25 لمدة بلأ 60 يوماً.

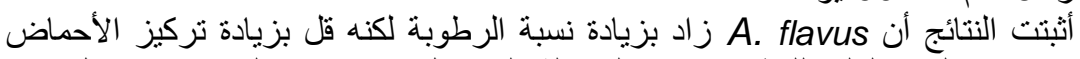

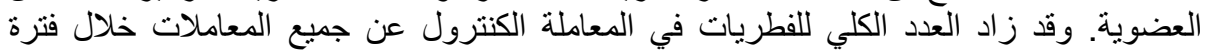

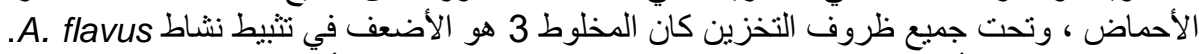

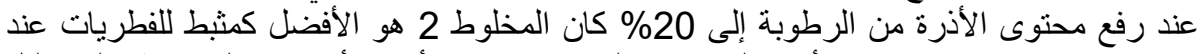

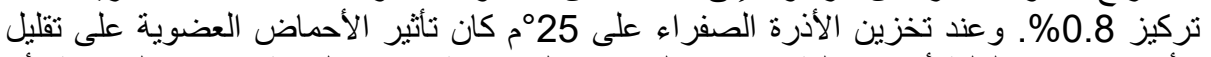

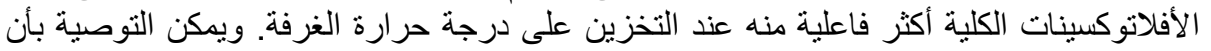

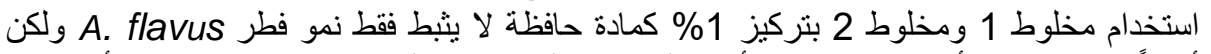

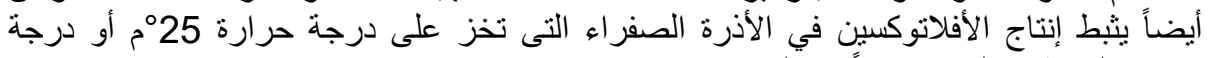
حر ارة الغرفة خلال 21 يوماً من التخزين. 